\title{
Ditadura militar, "terrorismo cultural" e censura a livros
}

Maria das Graças Targino*

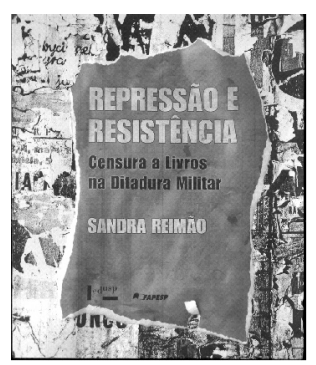

REIMÃO, Sandra. Repressão e resistência: censura a livros na Ditadura Militar. São Paulo: Edusp, Fapesp, 2011. 179 p.

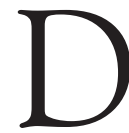
izem que o "hábito não faz o monge". Verdade absoluta. Não devemos julgar pessoas ou o quem quer que seja apenas pela aparência. No entanto, a publicação da professora e doutora Sandra Reimão, intitulada Repressão e resistência: censura a livros na ditadura militar, conquista o leitor à primeira vista, pela excelência de seu projeto gráfico. É uma edição primorosa da Editora da Universidade de São Paulo, em parceria com a Fundação de Amparo à Pesquisa do Estado de São Paulo.

Indo além da aparência, o conteúdo faz jus à excelência da apresentação gráfica. Trata-se de obra rigorosa. Lança mão de diferentes recursos para aprofundar a temática: consulta a arquivos oficiais; entrevistas com editores, livreiros, jornalistas e bibliófilos; contato sistemático com o Grupo de Pesquisa Produção Editorial da Intercom; e publicação de textos prévios, que permitem à autora rever conteúdos.

Como o título sugere, analisa o veto a livros durante a ditadura militar (1964 a 1985) vivenciada pela população brasileira.

\footnotetext{
* Pós-doutora em Jornalismo, Instituto Interuniversitario de Iberoamérica / Universidad de Salamanca /Universidade Federal do Piauí / Universidade Federal da Paraíba. Teresina-PI e João Pessoa-PB, Brasil.
}

Intercom - RBCC

São Paulo, v.35, n.2, p. 445-448, jul./dez. 2012 
Apesar da aparente rigidez do tema, é uma publicação da qual não conseguimos nos afastar durante a leitura. Enlaça-nos de forma inacreditável por seu nível de detalhamento; pela reprodução de belas capas de livros mencionados e pela completeza de dados. Traz informações preciosas. Como anexos, por exemplo, estão o Decreto-Lei n. 1.077, que detalha as medidas censórias; o rol dos livros proibidos pelo Departamento de Censura e Diversões Públicas; pareceres do Serviço de Censura e Diversões Públicas; balanço das atividades censórias de 1976 e informações sobre manifestações da sociedade.

Além do mais, se o texto de Reimão não assume as características de ensaio no sentido estrito do termo, possui linguagem "saborosa" e cuidada. É com um texto limpo, distante da caricatura do estilo acadêmico, que o capítulo inicial "Ditadura militar..." apresenta o panorama histórico da atuação dos censores frente às manifestações culturais, artísticas e editoriais. Nesse momento, a autora ressalta as contradições existentes, até porque, entre o golpe militar de 1964 e a promulgação do AI-5, "[...] a censura a livros no Brasil se caracteriza por atuação confusa e sem critérios definidos, mesclando batidas policiais, apreensões, confiscos e coerção física [...]" (REIMÃO, 2011, p. 20).

Os vetos atingem livros de ficção e não ficção. Dentre os últimos, estão obras que venceram o tempo e, hoje, persistem como clássicos. A revolução brasileira e $O$ mundo do socialismo, de Caio Prado Júnior, constituem significativos exemplos. Há livros de poesia. Há declarações de parlamentares. E, como previsível, a censura também atinge os jornais, fazendo com que os redatores adotem artifícios para salvaguardar os conteúdos, como Machado (1978) relata em livro-reportagem.

Há, ainda, cerco a livros eróticos ou pornográficos. Aliás, menção às escritoras a Adelaide Carraro e a Cassandra Rios remete à nossa adolescência e à inconfessável leitura de romances proibidos, devorados às escondidas. Também é interessante registrar que, se nos tempos atuais, há quem acuse a revista Veja de ser de "direita", também ela sofreu severas retaliações.

O segundo capítulo trata, especificamente, de dois livros censurados. Feliz Ano Novo, 1975, Editora Artenova, é de auto- 
ria do romancista, contista e roteirista Rubem Fonseca. Dono de estilo direto, sempre chamou a atenção para a violência urbana e a convivência entre marginalizados e autoridades, além de misturar história e ficção. Quanto ao conto Feliz Ano Novo, que dá nome ao livro proibido, a trama envolve três marginais que, movidos por violência insana, invadem uma festa de fim de ano numa casa de ricaços.

"Repressão e resistência..." traz à tona nomes de brasileiros ilustres e ainda atuantes. Exemplificando: o segundo livro analisado nesse capítulo refere-se a Zero: romance pré-histórico, de Ignácio de Loyola Brandão, romancista, contista, biógrafo e escritor de obras infanto-juvenis. A primeira edição brasileira data de 1975 e o veto à obra, do ano seguinte, diz que Zero... fala em "[...] personagens portadoras de complexos, vícios e taras [...] delinquência, suborno, latrocínio e homicídios [...]", sem referência a sanções (p.70).

Aguinaldo Silva, presença forte na dramaturgia brasileira e responsável por audiências memoráveis de minisséries e telenovelas da Rede Globo, também cai nas redes da censura. Para Reimão (capítulo três), a censura a Dez estórias imorais, ano 1967, resulta de parecer expedido, curiosamente, nove anos depois. Por isto, é possível que a repressão se vincule à atuação posterior do autor em publicações de oposição aos militares. São pequenos editores, livreiros, escritores desconhecidos e leitores que se unem a grandes nomes, como Jorge Amado e Érico Veríssimo, quando das manifestações em oposição à censura, com o fim de preservar os direitos humanos. Afinal, como Reimão (p.120) lembra, em certos momentos, ações corriqueiras, como "[...] comprar, carregar e guardar alguns livros podia ser perigoso".

Indo além, o quarto capítulo registra o veto a Em câmara lenta, de Renato Tapajós, 1977, sob a responsabilidade editorial de Alfa-Ômega. Segundo Mário Augusto Medeiros da Silva (2008, não paginado), seu lançamento converteu-se em ato político, com o adendo de que Tapajós constitui o único caso de autor preso, entre 1969 e 1974, por conta do conteúdo de um livro editado.

O quinto capítulo relata a reação da revista voltada ao público masculino, Status, diante da apreensão de dois dos contos premiados em duas edições do Concurso Nacional de Contos Eróticos: 
Mister Curitiba (1976), de Dalton Trevisan; e O cobrador (1978), de Rubem Fonseca. Ambos, apesar de proibidos como matérias na revista, são liberados para publicação em livro, enquanto o primeiro integra o título A trombeta do anjo vingador, Editora Codecri, 1977; O cobrador dá nome a livro de Fonseca, em 1979. Isto confirma que o veto a livros determinado pelos órgãos do Ministério da Justiça se caracterizou por clara ausência de parâmetros. Por tudo isto, vale a pena rememorar que a censura a livros, à época, se assemelha a uma modalidade de "terrorismo cultural", expressão cunhada por Alceu Amoroso Lima (Tristão de Athayde), hoje, distante da memória de muitos, sobretudo dos mais jovens. 